\title{
FLOOD RISK PERCEPTION, COPING AND MANAGEMENT IN TWO VULNERABLE COMMUNITIES IN KUMASI, GHANA
}

\author{
D.K. AHADZIE ${ }^{1}$, I. DINYE ${ }^{1}$, R.D. DINYE ${ }^{1}$ \& D.G. PROVERBS ${ }^{2}$ \\ ${ }^{1}$ Kwame Nkrumah University of Science and Technology, Ghana. \\ ${ }^{2}$ Birmingham City University, UK.
}

\begin{abstract}
Flooding has become an imminent and disruptive threat in many cities around the world. In developing/emerging economies, cities are often more vulnerable to the impacts of flooding. For example, in Accra, Ghana, recently over 150 people perished in a flash flood. The high casualty rate was a consequence of the lack of a well-developed integrated flood risk management plan and exacerbated by weak institutions, slums, urban sprawl and informal land / property management. To this effect, high risk countries like Ghana are in need of urgent development of systematic mitigation measures to engender community resilience (CS). Using the combined qualitative technique of Phenomenological Studies (PS) and Focus Group Discussions (FGDs), the flood risk perception, coping and management strategies of two vulnerable communities in the second largest city of Ghana, Kumasi are examined and evaluated for evidence of a sense of community resilience through social responsibility. The findings suggest that the two urban communities are aware they are at high risk to flooding and live in a constant state of anxiety during the wet seasons. However, there is no evidence of any systematic coping and management strategies and the communities feel there is nothing they can do without government support. It is suggested that government should use the leverage of local government practices to help engender a stronger sense of community empowerment and involvement towards building resilient communities that can respond to flooding through perceptions, social responsibility and appropriate public relation models.
\end{abstract}

Keywords: community resilience, coping strategies, flood management, flood risks, Ghana, Kkumasi, social responsibility.

\section{INTRODUCTION}

According to the Global Facilities for Disaster Reduction and Recovery reports, sub-Sahara Africa is acknowledged to be of high degree vulnerability to flooding and its devastating effects $[1,2]$. Exacerbated by climate change, population growth and increasing human activities, vulnerable communities in these countries are at more risk to urban flooding and there is the need for urgent collective action of preparedness to help mitigate the worst effects $[3,4]$. Contextually, some researchers have advocated for a high sense of community resilience (CS) to help vulnerable communities respond better to flooding; through perceptions, social responsibilities and appropriate public relation models [5]. Kellens et al. [6] have also epitomized on CS suggesting that, as a result of increasing global socio-economic challenges facing governments, the paradigm for flood risk management is now shifting; traditional 
measures being replaced by an integrated approach that emphasises social cohesion and preparedness of communities. Wood et al. [7] also argues in the same tone by imputing that, the human dimension in creating resilient communities in disaster management is now fully recognized and there is the need to understand the specific contributions for integrating such knowledge, interest and values in flood risk management. The World Bank's [8] recent development of an integrated Flood Risk Management handbook is also an affirmation of the global recognition attached to the need for collective efforts by nations and the citizenry to have a holistic approach for flood risk management.

It is established that flooding is a long standing hazard in Ghana and requires the development of an integrated flood risk management plan [9]. Following Ghana's worst flood disaster in June 2015 when 150 people lost their lives in the capital, Accra, the need to expedite action on developing a robust integrated flood risk management model is now imminent. However, most sub-Saharan Africa countries such as Ghana have weak economies and are often overwhelmed by the challenges posed by competing demands for limited public funds. It is thus expected that high risk communities in such countries will be dependent on traditionally acknowledged social networks to collectively plan and take appropriate action, towards building resilient communities. The paper reports on the findings of Focus Groups Discussions (FDGs) of two high risk communities; Sepe-Buokrom and Atonsu Ahinsan, in Kumasi, Ghana to establish their preparedness to deal with floods through community initiatives. The findings have policy implications for flood risk management in Ghana in helping stakeholders to understand the level of preparedness and adaptive capacity of potential communities to flood risk management.

An overview of the flooding situation in the literature, including the vulnerability and flood risk management in African cities such as Ghana is presented, including relevant theoretical frameworks. Subsequently, the procedure for the (FGDs) and how they were executed are enumerated. The data analyses and findings are then presented followed by policy implications.

\section{FLOOD HAZARDS IN DEVELOPING COUNTRIES- LITERATURE REVIEW}

Developing countries are noted to be at more risk to flood hazards because of their weak socio-economic indicators [3]. Accordingly Amoako [2], citing the IPCC [10], identifies two main contributing factors with respect to African economies; firstly, the continent is the most urbanized region with an average population growth rate of $4.4 \%$ against a global average of $2.5 \%$ [11] and secondly, Africa is most vulnerable to mitigating the effects of climate change. Thus, cities and conurbations in these countries are characterised by inadequate resources, lack of preparedness and low adaptive capacities and hence described as highly vulnerable. That is, floods easily overcome communities in these cities and represent considerable risks to their sustainable development [12]. Indeed, in the Ghanaian case, flooding has been a long standing hazard and needs prompt, effective and robust risk management efforts to mitigate its worst effects.

However, in Ghana as in many other African countries, there has been a dearth of research into flood risk management despite the considerable risks of flooding. It was not until the late 2000 that the interest started manifesting and within the last five years in particular, the focus is shifting towards searching for an effective flood risk management approach for vulnerable communities, with emphasis on human dimensions $[13,14]$. In Ghana some of the recent 
efforts are by Armah et al. [1]; Ahadzie and Proverbs [9]; Amoako [2]; Aboagye et al. [15]; Musa and Akai [14]. However, these papers focused on rural and farming communities as homogenous societies as opposed to urban settlements which are often heterogeneous and complex. Alternatively, in the sub-region, there is interest in, for example, Nigeria in also understanding how communities cope with and locally manage flood risk [13, 16-18]. Significantly, Olorunfemi and Raheem's [16] paper focusing on Ilorin, Kwara State is of much interest here because of its urban nature. Olurunfemi and Raheem [16] adopting a quantitative approach concluded that house characteristics and neighbourhood quality contribute significantly to vulnerability to rainstorm and flooding. In this study a qualitative approach is adopted towards developing insight into the coping and adaptive capacity of two Ghanaian communities described as high risk in terms of flooding.

Similarly, the global literature is also increasingly focusing on addressing integrated flood risk management from the social and community perspective; as in for example Eastern Europe [19] Western Europe [5], Asia [20] and the Americas [7]. This paper draws lessons on concepts and variables used in the increasingly global literature to shape the questions asked in the FGDs.

\section{THEORETICAL FRAMEWORK AND FOCUS GROUP APPROACH}

According to Jonkman and Dawson [20] recent flood events have exposed the weaknesses in engineering systems in many cities across the globe calling for the need for human operations before, during and after flooding to be examined. Here, Kellens et al. [6] identify various methods that could be used in understanding the perception and coping of flood risk ranging from psychometric paradigms, heuristics, and adaptive behaviours such as mitigation, preparedness and recovery and other qualitative approaches involving mental models approach. Wood et al. [7] also highlight key items that can be used to understand the psychological models of laypersons on topics related to flooding such as concept mapping, decision support systems, strategic environmental assessments, flood risk management diagrammatic reasoning, logical argument mapping, risk ranking, shared mental model and team mental model. As this study is focused on understanding the adaptive preparedness of communities that are at high risk of floods from their own perspective, the qualitative approach of Focus Group Discussions (FGDs) was used in gathering the data. However, lessons from the above mentioned theoretical frameworks among others were used in posing questions under four major thematic areas, namely; Flood risk, coping strategies, management and sustainability. The FGDs were utilized to collect information on the experiences of flood victims relating to the socio-economic characteristics of the victims, causes and effects of flooding, their coping mechanisms as well as their adaptation measures. Details of the specific questions have been deleted because of restrictions on the length of the paper. The FGDs also covered issues such as perceptions on flood insurance, what government could do and what the community could do to lessen the effects of flooding. The (FGDs) were conducted in Sepe-Buokrom and Atonsu Ahinsan, two communities identified as prone to repeated flooding in Kumasi [21]. In selecting the participants for the FGDs, individuals who had experienced flooding in the last 10 years were targeted for the study, including those from different socio-cultural and economic groups; including men and women, youths, artisans, food vendors, traders, farmers, and house owners among others. These participants were identified with the assistance of the government elected representative in the community locally known as "Assemblyman". 


\section{DESCRIPTION OF THE STUDY AREA}

The study was conducted within Kumasi, the second largest city in Ghana, located in the rainforest zone of West Africa between latitude $6^{\circ} 30^{\prime}$ and $7^{\circ} 00^{\prime} \mathrm{N}$ and longitude $1^{\circ} 30^{\prime}$ and $2^{\circ} 00^{\prime} \mathrm{W}$. Kumasi has a wet, semi-equatorial climate with an annual rainfall of around $1,400 \mathrm{~mm}$ with two distinct rainy seasons. The mean annual temperature is $25.7^{\circ} \mathrm{C}$ with a humidity ranging from 53\% to 93\% [21]. Kumasi has a population of 2,035,064 in 2010 and recorded an annual population growth rate of 5.7\% between 2,000 and 2,010 [22]. In response to the population increase Owusu-Ansah [23] alludes that land use has intensified into the inner city and spilled over into the city's public parks and natural vegetation of open spaces, riparian lands and wetlands hence creating large areas with impervious surfaces and increased volumes of runoff from precipitation.

Owusu Ansah [23] further relates that since the 1980s, when a system of open drains were established as part of the major road rehabilitation programme very few improvements have been made to drainage infrastructure. Figure 1 shows the main locations in Kumasi noted to be flood prone and the study areas; Sepe-Buokrom and Atonsu-Ahinsan. Atonsu-Ahinsan is characterized by houses made up of cement and sand walls roofed with corrugated iron sheets and many houses are clustered together with little spaces between them; there are very few well planned roads and this gives an impression of poorly planned closed community. Choked gutters were common and the drainage system is quite poor. The economic activity in this study area is mostly small scale self-employed businesses and petty trading [21].

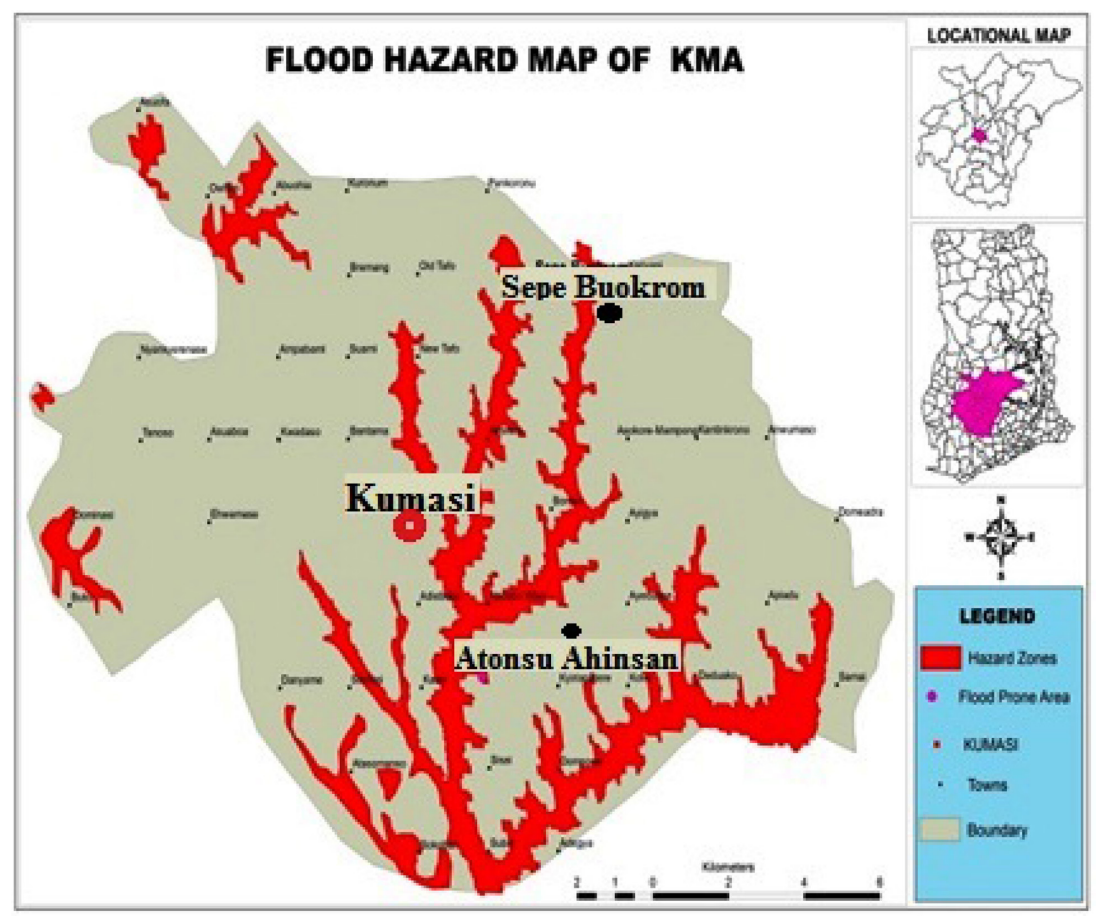

Figure 1: Map of Kumasi showing flood prone areas. 
In spite of annual flooding, the Sepe-Buokrom area has experienced some level of urban development. In addition, unauthorized structures have further extended the settlement into floodable areas [23].

\section{THE FOCUS GROUP DISCUSSIONS}

The preparation towards the FGDS started in mid-February when contacts were made with the assemblymen of the various high risk communities, through a phone call to establish an audience with them on the rational for the study. Based on an initial review of literature by Owusu Ansah, (2013) in Kumasi, three main areas were identified as flood prone; SepeBuokrom and CPC and Atonsu-Ahinsan areas of Kumasi, the second largest city in Ghana. Initially, all three Assemblymen agreed to assist in identifying the potential participants, however close to the appointed times agreed, the Assemblyman for $C P C$ asked for extension of time for some health reasons, however, because time was running out, the FDGs was held in the two communities, Sepe-Buokrom and Atonsu-Ahinsan.

Following the initial phone conversations with the Assemblymen of the selected communities, a visit was made to Sepe - Buokrom on 5/02/2016 to meet with the Assemblyman to discuss the rationale of the FDGs and the role he was expected to play in facilitating the exercise. Having reached an understanding on the modalities, the date for the FGDs was fixed for $12 / 02 / 2016$. On the appointed day, three members of the research team met the group for the exercise. The research team comprised a moderator of the FGDs, a recorder and an observer of the general mood and body language of the participants. In Sepe-Buokrom, the FGDs began at 9.00 am and ended at $10.25 \mathrm{am}$. The participants comprised of 12 participants; 5 males and 7 females. Analysis of the general background information obtained from the participants indicates that they have all lived in the community for at least 10 years and have experienced repeated flooding in the community. The participants are mostly selfemployed engaged in livelihoods ranging from artisans, food vendors, drivers and vehicle owners. The general atmosphere in the hall where the FGDs was held was a sign of cordiality and all participants were relaxed. There was no sign of intimidation as all participants expressed themselves freely. The Assemblyman also participated in the exercise both as a victim of flood and also as the elected representative of the community at the local government office. Generally, the housing characteristics of the neighbourhood are of poor quality characterised by haphazard development with some houses having their foundations exposed, suggesting signs of erosion; lack of paved streets and roads, absence of gutters and drainage facilities within the community, deep gullies in some areas and informal business and commercial activities.

As in Sepe Buokrom, a preliminary visit was made to meet the Assemblyman for the Atonsu-Ahinsan area to discuss the details of the FGDs and fix an appropriate date. Subsequently, the FGDs was initially fixed for 18/03/2016 but had to be rescheduled following bereavement in the community that week. Finally, the FGDs took place on 25/02/2016. The discussion began at 10.00 am and ended at 11.45 am lasting close to 2 hours. The FGDs comprised of 8 participants; 4 men and 4 women, including the Assemblyman. Background information gathered indicates that the participants had lived in the area for at least 10 years and had experienced several floods.

All participants of the FGDs in Atonsu-Ahinsan were self-employed; farmers and petty traders and they intimated that their livelihood had deteriorated due to the flooding. Similar to Sepe-Buokrom their housing conditions are characterised by exposed foundations of 
houses and cracks in buildings, lack of paved streets and roads, absence of gutters and drainage facilities within the community, deep gullies in some areas and informal business and commercial activities.

\section{RESULTS}

The data have been transcribed from the local dialect Asante Twi to English as close to verbatim as possible (the details are not included because of restrictions on the length of paper). The data were analyzed manually in the first instance individually by three researchers and later the findings emerging were compared in a collective discussion to reach a consensus on the realistic representation of the concepts emerging as listed in the quotations and Table 1 below.

With respect to risk levels in the two communities, these are the comments made by the respondents:

"The source of the river is at Buokrom Estate, and the river from Pakrono joins into the Buokrom Estate one. So it may not necessarily rain here but once it rains at Pankrono this whole area will be flooded. So by the time it begins to rain here the whole place will already be flooded because it is a low lying area. When it rains in the whole Kumasi it is even worse."

Table 1: Summary of findings from focus group discussions.

\begin{tabular}{|c|c|c|c|}
\hline $\begin{array}{l}\text { Thematic } \\
\text { Area }\end{array}$ & Sepe Buokrom & Atonsu Ahinsan & Emerging Concepts \\
\hline $\begin{array}{l}\text { Flood Risk } \\
\text { perception }\end{array}$ & $\begin{array}{l}\text { Physical observation, as } \\
\text { soon as clouds gather, high } \\
\text { risk area, }\end{array}$ & $\begin{array}{l}\text { Physical Observation; } \\
\text { as clouds gather, high } \\
\text { risk area }\end{array}$ & $\begin{array}{l}\text { Rain is analogous to } \\
\text { flooding high risk area }\end{array}$ \\
\hline Causes & $\begin{array}{l}\text { Human activity, haphaz- } \\
\text { ard construction, lack of } \\
\text { drains, dumping of refuse, } \\
\text { fluvial flooding and flash } \\
\text { flooding }\end{array}$ & $\begin{array}{l}\text { Fluvial flooding, in- } \\
\text { complete construction } \\
\text { of covert, dumping of } \\
\text { refuse into gutters }\end{array}$ & $\begin{array}{l}\text { Fluvial flooding, flash } \\
\text { flooding, weak or } \\
\text { non-existent engineer- } \\
\text { ing systems, human } \\
\text { activity }\end{array}$ \\
\hline $\begin{array}{l}\text { Coping } \\
\text { strategies }\end{array}$ & Anxiety & Anxiety & Anxiety \\
\hline Management & $\begin{array}{l}\text { No management plan cur- } \\
\text { rently in place. But school } \\
\text { buildings were considered } \\
\text { a good gathering point } \\
\text { during flooding. }\end{array}$ & $\begin{array}{l}\text { School buildings are } \\
\text { natural choice gather- } \\
\text { ing points but not } \\
\text { based on any commu- } \\
\text { nity agreement. }\end{array}$ & $\begin{array}{l}\text { Mostly no concise and } \\
\text { management plan in } \\
\text { place. }\end{array}$ \\
\hline $\begin{array}{l}\text { Emerging } \\
\text { Concepts }\end{array}$ & $\begin{array}{l}\text { Resilience and Social } \\
\text { Responsibility practically } \\
\text { non-existent. } \\
\text { No trust in any form of } \\
\text { insurance scheme }\end{array}$ & $\begin{array}{l}\text { Resilience and social } \\
\text { responsibility } \\
\text { practically non-exist- } \\
\text { ent. } \\
\text { No trust in any form } \\
\text { of insurance scheme }\end{array}$ & $\begin{array}{l}\text { Resilience and social } \\
\text { responsibility practi- } \\
\text { cally non-existent. } \\
\text { No trust in any form } \\
\text { of insurance scheme }\end{array}$ \\
\hline
\end{tabular}


"One main area is the flooding of the Airport roundabout area. When the place floods you can't go anywhere. The whole area gets flooded from here to Dichemso" and if care is not taken you can even die. All the governments are aware of this problem but nothing has been done to alleviate the problem, if we had gutters and bridges we would not encounter these problems. All this we have come here today to say, you will take it up but nothing will be done about."

"Sometimes when it rains at Ahinsan you may think it will not flood the area, but when the water joins with that of the town then we have a problem. So for me when it begins to rain I do not sleep."

When the participants were asked to explain some indigenous signs of flooding, the general response was as follows:

"The main sign is the gathering of clouds and the possible threat of rain. In this area, whenever it threatens to rain there is a lot of apprehension because of the effects of drowning we have encountered".

On the causes of floods in the communities, this is how they responded:

"This area is an old town and when buildings were put up in the past, buildings were not properly delineated for streets and drainage systems. As a result, when it rains some houses are immersed in rain water up to the knee level. All these things bother us, whenever it rains if caution is not taken adults can even drown".

These are some revealing stories of the personal experience of some participants

"Last year my wife went to town and the vehicle she was in could not come through to our community because of the flood. I had to go out in my underwear to pick my wife. That day That day I had to carry 17 more people and also accommodate 10 more people that night".

"I was returning from town and the entire airport roundabout area had flooded, one man who was with us was carried away by the water".

"I lived in a story building (means multi-story building) and last year the entire ground floor got flooded and the tenants lost all their belongings and 8 people moved out. That day it rained from evening till dawn, the whole ground flooded".

"Some years ago I lost close to 3000 poultry which was my family's source of livelihood...Some machines got stuck in the water and there was the need to destroy my coup in order access them... There was no compensation and till date we haven't been able to work again and in spite of this we still encounter problems due to the flood".

"We stood outside for a while because there was nowhere to go. At some point we had no choice but sleep on our wet mattress...we purchased a rubber (polythene sheet) to cover it in order to sleep with the water still draining out in the process".

These are some feelings expressed regarding willingness to participate in any kind of flood insurance scheme: 
"We have heard of flood insurance, in the past I had four cars but when there was a problem I got tossed around so in the end I sold the cars. As a result, I believe even if I purchase any insurance, I will not be able to reap the benefits unless I'm dead... When they visit you, their packages seem very attractive but when you require assistance they can even tell you they can't find your file".

"Here in Ghana the insurance companies do not abide by the rules unlike other countries, so no one really trusts them"

"If a community initiative to collect funds to assist flood victims is introduced, it will not work because some community members will not participate fully. The programme will work if only a community forum is organized. Some education will be required about the insurance."

"It would be good but I think it shouldn't be done, because of the tendency of those in charge to spend the funds."

Some flood coping strategies of the respondents were as follows:

"For individuals living in low lying areas, whenever flooding occurs they stand on their beds with their belongings. So when it is not raining we are all relaxed but the moment we see signs of rain there is a lot of anxiety."

"I am a widow and I am alone with my children... so when it begins to rain I let my children sleep first and then I keep vigil because my wall is already broken as a result of the flooding".

In relation to community participation in lessening the effects of flooding the participants expressed that:

"We have self-help projects that the community should involve themselves. But in this community if you speak to people about something that doesn't directly affect them they are unwilling to participate. There are some people who will not even come and share their condolences so how much more will they contribute to a programme like this".

"Personally I feel that the victims of flooding should form a group and forget about the entire community because they cannot understand our problems".

"In the past, the traditional leaders had more control of the communities, but right now the jurisdiction is in the hand of the local government who charges us for the use of every utility. Now we have to pay for everything including toilet facilities and dumping refuse. So now we don't want to participate in any community activities because we feel it's the duty of the local government"

These findings suggest that in the Sepe-Buokrom area, the main cause of flooding is the absence of gutters and drains within the community. Coupled with this, is the problem of residents dumping refuse in the gutters of the main streets of the communities and the rivers. The most vulnerable groups are residents in the low lying grounds in the Moshie Zongo area who are notably migrants. Among the effects of flooding are the loss of lives, livelihoods and 
property, the inability to access social amenities and infrastructure and the inability of individuals to move from one place to the other during rains and subsequent flooding. Similarly, in the Atonsu Ahinsan area flooding is mainly as a result of the gathering of rain water in an uncompleted culvert and choked gutters as a result of the dumping of refuse. The major effect of flooding in this area is mostly loss of livelihoods and property making it difficult for victims of flood disasters to put their lives back in order after the floods has subsided. In both communities there was a strong request for government to provide services to prevent flooding and or otherwise curb flood disasters. Apart from monthly communal labour activities to clear gutters as well as the filling of gullies with big stones, there are no community or individual initiatives to lessen the effects of flooding. In spite of the frequent flooding of the area, there is no flood risk management plan in place which is exhibited by the absence of a designated gathering point or contact person during flooding. There was the general consensus that an introduction of flood insurance is a good initiative, however, both communities were highly sceptical based on the general perception of the poor image of the insurance industry in Ghana.

\section{DISCUSSION}

This study has established that the participants used for the FGDs from the two communities Sepe Buokrom and Atonsu-Ahinsan are fully aware that their communities are high risk flood areas and that both communities are vulnerable. Flooding has emerged as the most devastating natural hazard and developing countries such as Ghana are at most risk demanding the development of robust mitigation measures [9]. Against the background of recent flooding, Ghana now requires having a holistic approach towards flood control and management, especially as the vulnerability of engineering and economic system and also communities are being exposed. An effective flood risk management approach has to include the connection between construction infrastructure, economic system and the role of human factors [20]. However, the FGDs have revealed that some vulnerable communities in Ghana which could be described as high risk are generally in a state of constant trepidation and looking for government support. Given that flooding is often widespread, uncontrollable and devastating, it is indeed normal for communities to look up to Governments who often have the leverage to provide the kind of assistance needed. For instance, Wood et al [7] has noted that, even in developed economies such as the US where there is relatively high awareness and involvement of communities, many communities still expect the government to take the full burden of flood risk management, including those effecting their personal loss and liability. However, it is also now known that societal drivers in terms of social responsibility and willingness to prepare for an event and knowing how to prepare is also crucial in building CS to flood hazards $[5,6]$. The emerging trend is that, flood risk management is shifting from the traditional objective approach to an integrated approach with the focus on social aspects and preparedness of communities incorporated into community knowledge [6].

In Ghana, the National Disaster Management Organisation (NADMO) is the government agency responsible for the management of floods as well as other emergencies in Ghana. NADMO performs specific functions which are all aimed at ensuring that in times of emergency, the government is ready to support with relief efforts. The evidence on the ground is that the NADMO has been slow in reacting to the emerging trends and concentrate too much on providing relief items (which are limited anyway) to the victims. Flood hazard is expected to exacerbate due to increases in human activity and climate change, and consequently flood 
vulnerability will be expected to increase. It is therefore high time that the NADMO of Ghana re-align by expanding their activities to help build resilience communities by tapping into the concept of social responsibility.

Traditionally, many African societies are said to be closely knit as a result of the extended family system. The literature in Ghana has demonstrated this perhaps is still workable in the rural communities [4] However, in the urban centres it is not exactly clear whether this assertion holds true. The FDGs has revealed that there is not enough collective action in the communities and that it will require more active intervention at all levels to engender this sense of social responsibility so that Ghanaian communities would begin to embrace the concept as a core societal obligation towards mitigating flood hazards.

\section{CONCLUSION}

This paper used FDGs to establish whether there is any sense of CS through social responsibility in Sepe-Buokrom and Atonsu-Ahinsan, two high-risk communities to flooding in Kumasi, Ghana. The findings revealed that even though the two communities are not oblivious of the fact that, their communities are high risk, they lack any systematic effort in taking the initiative to contribute in developing their adaptive capacity to help manage floods. Emerging issues suggest that it will need a lot of deep understanding of community perceptions, actions and behaviours for them to be convinced in living to their social responsibility [7]. The decentralization concept in Ghana allows for the election of local representatives of community members called Assemblymen and their Unit committee members. The FDGs has revealed that, the Assemblymen and the committee members have not been able to provide the necessary leadership to the respective communities regarding their social responsibility. As a matter of policy, it would be important for the Assemblymen to be empowered to meet the community regularly and provide regular plans to the NADMO and the local government on efforts towards building an effective integrated flood risk management system for their communities.

\section{REFERENCES}

[1] Armah, F.A., Yawson, D.O., Yengoh, G.T., Odoi, J.O. \& Afrifa, E.K., Impact of floods on livelihoods and vulnerability of natural resource dependent communities in Northern Ghana. Water, 2(2), pp. 120-113, 2010.

http://dx.doi.org/10.3390/w2020120

[2] Amoako, C., Emerging issues in urban flooding in African cities-the case of accra, Ghana. In 35th AFSAAP Annual Conference Proceedings, 2012.

[3] Jha, K.A., Bloch, R. \& Lamond, J., Cities and Flooding: A Guide to Integrated Urban Flood Risk Management for the 21st Century, The World Bank: Washington DC, 2011.

[4] Fabiyi, O.O. \& Oloukoi, J., Indigenous knowledge system and local adaptation strategies to flooding in coastal rural communities of Nigeria. Journal of Indigenous Social Development, 2(1), pp. 1-19, 2013.

[5] Mullins, A. \& Soetanto, R., International. Journal of Safety and Security Engineering, 1(2), pp. 115-125, 2011. http://dx.doi.org/10.2495/SAFE-V1-N2-115-125

[6] Kellens, W., Terpstra, T. \& De Maeyer, P., Perception and communication of flood risks: a systematic review of empirical research. Risk Analysis, 33(1), pp. 24-49, 2013. http://dx.doi.org/10.1111/j.1539-6924.2012.01844.x 
[7] Wood, M., Kovacs, D., Bostrom, A., Bridges, T. \& Linkov, I., Flood risk management: US Army Corps of Engineers and layperson perceptions. Risk analysis, 32(8), pp. 1349-1368, 2012. http://dx.doi.org/10.1111/j.1539-6924.2012.01832.x

[8] World Bank, Cities and Flooding: A Guide to Integrated Urban Flood Risk Management for the $21^{\text {st }}$ Century, 2015.

[9] Ahadzie, D.K. \& Proverbs, D.G., Emerging issues in the management of floods in Ghana. International Journal Safety Security Engineering, 1(1), pp. 182-192, 2011. http://dx.doi.org/10.2495/SAFE-V1-N2-182-192

[10] Intergovernmental Panel on Climate Change, IPCC, Summary for Policymakers. In Managing the Risk of Extreme Events and Disasters to Advance Climate Change Adaptation, Special Report of Working Groups 1 and 11 of the Intergovernmental Panel on Climate Change, eds. C.B. Field, V. Barros, T.F. Stocker, D. Qin, D.J. Dokken, K.L. Ebi, M.D. Mastrandrea, K.J. Mach, G.K. Plattner, S.K. Allen, M. Tignor \& P.M. Midgley, Cambridge University Press: Cambridge, UK, and New York, NY, USA, pp. 1-19, 2012.

[11] UN Habitat 2011, Global Report on Human Settlements 2011: Cities and Climate Change, United Nations Human Settlements Programme (UN Habitat), Earthscan: London UNISDR, 2012.

[12] Perdikaris, J., Gharabaghi, B. \& McBean, E., A methodology for undertaking vulnerability assessments of flood susceptible communities. International Journal of Safety and Security Engineering, 1(2), pp. 126-146, 2011. http://dx.doi.org/10.2495/SAFE-V1-N2-126-146

[13] Olugunorisa, T.E., Strategies for mitigation of flood risk in the Niger Delta, Nigeria. Journal of Applied Sciences and Environmental Management, 13, (2), pp. 17-22, 2009.

[14] Musah, B.A.N. \& Akai, C.Y., Effects of flood disasters on livelihood coping mechanism in Tolon/Kumbumgu District of Northern Region of Ghana. International Journal of Agricultural Policy and Research, 2(1), pp. 33-40, 2014.

[15] Aboagye, D.D., Dari, T. \& Koomson, J., Risk perception and disaster management in the savannah region of Ghana. International Journal of Humanities and Social Science, 3(3), pp. 85-95, 2013.

[16] Olorunfemi, F.B. \& Raheem, U.A., Floods and rainstorms impacts, responses and coping among households in Ilorin, Kwara Stat. Journal of Educational and Social Research, 3(4), pp. 135-144, 2013. http://dx.doi.org/10.5901/jesr.2013.v3n4p135

[17] Thompson, P. \& Tod, I., Mitigating flood losses in the active floodplains of Bangladesh. Disaster Prevention and Management: An International Journal, 7(2), pp. 113-123, 1998.

http://dx.doi.org/10.1108/09653569810216333

[18] Anikpo, M., Ogbanga, M.M., Ifeanacho, M., Flood disaster, adaptation and coping strategies in selected communities of Ahoada East and Ahoada West local government areas, rivers state. IIARD International Journal of Environmental Research, 1(3), pp. $1-12,2015$.

[19] Duží, B., Vikhrov, D., Kelman, I., Stojanov, R. \& Juřička, D., Household measures for river flood risk reduction in the Czech Republic. Journal of Flood Risk Management, pp. 1-14, 2015.

http://dx.doi.org/10.1111/jfr3.12132 
[20] Jonkman, S.N. \& Dawson, R.J., Issues and challenges in flood risk management-editorial for the special issue on flood risk management. Water, 4(4), pp. 785-792, 2012. http://dx.doi.org/10.3390/w4040785

[21] Tay, S.C.K., Danuor, S.K., Morse, A., Caminade, C., Badu, K. \& Abruquah, H.H., Entomological survey of malaria vectors within the kumasi metro area-a study of three communities: Emena, Atonsu and Akropong. Journal of Environmental Science and Engineering B1(2012), pp. 144-154, 2015.

[22] Ghana Statistical Services, Population and Housing Census, 2010.

[23] Owusu -Ansah, J.K., The influences of land use and sanitation infrastructure on flooding in Kumasi, Ghana. Geojournal of Spatially Integrated Social Science and Humanities, 80(1), 2015.

http://dx.doi.org/10.1007/s10708-015-9636-4

[24] Government of Ghana. Local Government Act 462:1993. 